\title{
Tricyclic antidepressants block cholinergic nicotinic receptors and ATP secretion in bovine chromaffin cells
}

\author{
Victor Izaguirre, José M. Fernández-Fernández, Valentín Ceña, Carmen González-García* \\ Departamento de Farmacología and Instituto de Neurociencias, Universidad Miguel Hernández, Campus de San Juan, E-03550 San Juan (Alicante), \\ Spain
}

Received 13 August 1997; revised version received 15 October 1997

\begin{abstract}
Nicotine-induced ATP secretion from chromaffin cells was blocked by imipramine and desipramine. This blocking action took place on both, fast and slow, components of ATP secretion. Exposure of chromaffin cells to nicotine $(10 \mu \mathrm{M})$ for $4 \mathrm{~s}$ induced an inward current of about $-155 \mathrm{pA}$. Imipramine and desipramine blocked, in a concentration-dependent manner, both peak inward current and total charge influx in response to nicotine. In addition, imipramine and desipramine partially $(40 \%)$ blocked depolarization-induced ATP secretion and $\mathrm{Ca}^{2+}$ currents evoked by high $\mathrm{K}^{+}$. This suggests that tricyclic antidepressants block nicotine-induced $\mathrm{ATP}$ secretion by acting on two targets: one is the nicotinic receptor itself and the second one are voltage-dependent $\mathrm{Ca}^{2+}$ channels.
\end{abstract}

(C) 1997 Federation of European Biochemical Societies.

Key words: Nicotine; ATP secretion; Chromaffin cell; Imipramine; Desipramine; Calcium channel

\section{Introduction}

Tricyclic antidepressant drugs have been widely used to block catecholamine uptake-1 transport system (for review see [1]). However, in addition to this pharmacological property, these drugs also produce blockade of cholinergic muscarinic [2] and nicotinic [3] receptors and a-adrenoceptors [4]. Pharmacological actions on these sites may be responsible for the known side-effects of tricyclic antidepressant drugs.

Chromaffin cells secrete catecholamines (CA) and ATP in response to different stimuli (for review see [5]). Under physiological conditions, acetylcholine is released from splanchnic nerve terminals and interacts with nicotinic receptors producing depolarization of chromaffin cell membrane [6,7]. This depolarization opens voltage-dependent $\mathrm{Ca}^{2+}$ channels $[8,9]$, which produce an increase in intracellular $\mathrm{Ca}^{2+}$ levels $\left(\left[\mathrm{Ca}^{2+}\right]_{i}\right)$ [10] and CA and ATP secretion [11].

In addition to cholinergic agonists, neuronal nicotinic receptors located in bovine chromaffin cells are also targets for a variety of drugs and toxins, like L-type voltage-dependent $\mathrm{Ca}^{2+}$ channel blockers [12], $\omega$-conotoxin GVIA, a toxin from the snail Conus geographus which is a selective blocker of N-type voltage-dependent $\mathrm{Ca}^{2+}$ channels [13], $\omega$-agatoxin IVA, a specific blocker of P-type voltage-dependent $\mathrm{Ca}^{2+}$ channels obtained from the spider Agelenopsis aperta [14] and the diuretic cyclothiazide [15] whose interaction with the nicotinic receptor blocks its function. In a previous work, it was showed that, when imipramine was used as uptake-1 transport system blocker in chromaffin cells to enhance CA

*Corresponding author. Fax: +34 (6) 5903902.

E-mail: gonzalez@,umh.es secretion in response to nicotine, CA secretion was markedly decreased in a dose-dependent fashion [16].

To identify the target for the observed blocking actions of tricyclic antidepressants on secretion from chromaffin cells, we have studied the effect of imipramine and desipramine, on depolarization-induced $\mathrm{Ca}^{2+}$ currents, nicotinic receptor-activated currents and ATP secretion induced by either cholinergic nicotinic agonists or high $\mathrm{K}^{+}$depolarization and the kinetics of ATP (co-released with $\mathrm{CA}$ during exocytotic secretion) release. We have found that both imipramine and desipramine inhibited, in a dose-dependent manner, nicotineinduced and voltage-dependent $\mathrm{Ca}^{2+}$ currents and this effect might explain its inhibitory action on nicotine-induced ATP secretion.

\section{Materials and methods}

\subsection{Cell isolation and culture}

Bovine chromaffin cells were isolated using collagenase digestion and purified through a Percoll gradient as previously described [13]. Isolated cells were plated in culture flasks for ATP secretion experiments at a density of $0.5 \times 10^{6}$ cells $/ \mathrm{ml}$. For electrophysiological recordings $10^{6}$ cells were suspended in $2 \mathrm{ml}$ of culture medium and plated in a $35 \mathrm{~mm}$ diameter petri dish (Bibby Science Products, Stone, England). Cultured cells were kept at $37^{\circ} \mathrm{C}$ under an atmosphere of $5 \% \mathrm{CO}_{2}$.

\subsection{Electrophysiological recording}

2.2.1. Nicotinic receptor currents. Recording of chromaffin cell nicotinic receptor-activated currents under voltage-clamp was done, using the nystatin-perforated patch-clamp technique, as previously described [14]. Chromaffin cells were bathed in a solution with the following ionic composition (in mmol/l): $\mathrm{NaCl} 140 ; \mathrm{KCl} 5.9 ; \mathrm{MgSO}_{4}$ 1.2; $\mathrm{CaCl}_{2}$ 2.5; HEPES 15 and glucose 11 (pH 7.4). The intracellular solution had the following composition (in mmol/1): $\mathrm{KCl} 55 ; \mathrm{K}_{2} \mathrm{SO}_{4}$ $50 ; \mathrm{MgSO}_{4} 7$; HEPES 10 and nystatin $250 \mu \mathrm{g} / \mathrm{ml}$ (pH 7.2). After 10 min, nicotine $(10 \mu \mathrm{M})$ was applied for $4 \mathrm{~s}$ using a fast perfusion system under computer control (DAD-12 superfusion system; Adams and List, NY). This nicotine pulse was repeated 3 times $\left(S_{1}, S_{2}, S_{3}\right)$ at 15 min intervals. When used, tricyclic antidepressants were present 5 min before and during $\mathrm{S}_{2}$

2.2.2. Voltage-dependent $\mathrm{Ca}^{2+}$ currents. For $\mathrm{Ca}^{2+}$ current recording, the extracellular solution had the following composition (in mmol/l): choline $\mathrm{Cl} 140 ; \mathrm{KCl} 5 ; \mathrm{CaCl}_{2} 2.5 ; \mathrm{MgCl}_{2} 1 ;$ HEPES 10 and glucose $11(\mathrm{pH}$ 7.4). Since it has been described that choline is a partial agonist for cholinergic nicotinic receptors [17] and stimulation of nicotinic receptors by the high doses of choline used in the extracellular solution might change $\left[\mathrm{Ca}^{2+}\right]_{i}$, the cholinergic nicotinic blocker D-tubocurarine $(10 \mu \mathrm{M})$ was added to the extracellular medium. The ionic composition of the pipette solution was the following (in mmol/1): $\mathrm{CsCl} 55 ; \mathrm{Cs}_{2} \mathrm{SO}_{4} 50 ; \mathrm{MgSO}_{4} 7$; HEPES 10 and nystatin $250 \mu \mathrm{g} / \mathrm{ml}(\mathrm{pH} 7.2)$. A single pulse $\left(\mathrm{S}_{1} ; 10 \mathrm{~s}\right)$ was applied from a holding potential of $-55 \mathrm{mV}$ to $+5 \mathrm{mV}$. This pulse protocol was repeated, at $10 \mathrm{~min}$ intervals $\left(\mathrm{S}_{2}, \mathrm{~S}_{3}\right)$. These records were acquired at a sampling rate of one point every $5 \mathrm{~ms}$ and filtered at $1 \mathrm{kHz}$. Tricyclic antidepressants, when used, were present $5 \mathrm{~min}$ before and during $S_{2}$. Time integrals of the current records were used to calculate total charge and $\mathrm{Ca}^{2+}$ influx. Voltage pulse protocols and current 

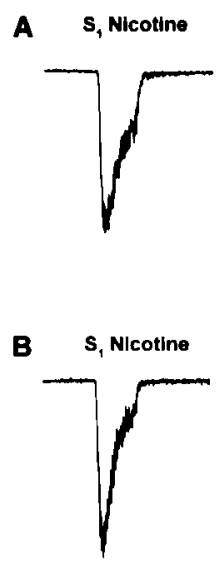

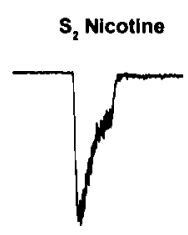

$S_{2}$ Nicotine +

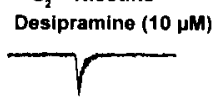

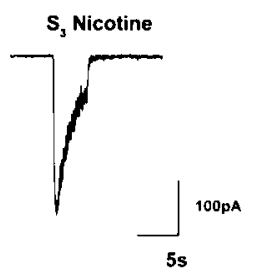

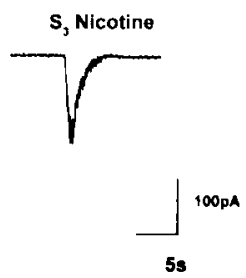

Fig. 1. Nicotine-induced inward currents in chromaffin cells. A: Inward currents evoked by 3 successive exposures $\left(S_{1}, S_{2}, S_{3}\right)$ of one chromaffin cell to nicotine $(10 \mu \mathrm{M})$ for $4 \mathrm{~s}$ from a holding potential of $-55 \mathrm{mV}$. B: Same as in $\mathrm{A}$, but 5 min before and during $\mathrm{S}_{2}$, desipramine (10 $\mu \mathrm{M})$ was present. The experiment was repeated 4 times with similar results.

transient recordings were under computer control. The linear component of the capacity transient was subtracted using a P/4 protocol [18]. The non-linear components were digitally subtracted [9]. The open tip resistance of the pipettes ranged between 3 and $5 \mathrm{M} \Omega$ and were covered to near the tip with Sylgard to decrease capacitance. Capacity transients were cancelled using the built-in circuitry of the patchclamp amplifier (EPC-7, List, Darmstadt, Germany) and the pipette potential set at $-55 \mathrm{mV}$. The average capacitance of the cells was $11.23 \pm 0.5 \mathrm{pf}$ and the series resistance $\left(R_{\mathrm{s}}\right) 12.8 \pm 0.92 \mathrm{MW}(n=18)$. No compensation for $R_{\mathrm{s}}$ was used.

\subsection{ATP secretion}

ATP release in response to high $\mathrm{K}^{+}$or nicotine was determined using the luciferin luciferase (L-L) method as previously described [19]. Briefly, after 48 to $72 \mathrm{~h}$ in culture, cells were mechanically detached from cultured flasks, centrifuged and resuspended at a density of 2000 cells $/ \mu 1$. ATP secretion was determined on-line, using the L-L method, in a final volume of $200 \mu \mathrm{l}$ containing $5 \times 10^{4}$ cells [19]. This low density of cells used in these experiments was required to minimize ATP hydrolysis by ectoATPases [20]. Total ATP content in the cell was determined by solubilizing the cells using Extralight (Analytical Luminescence, San Diego, CA).

Records of secretory response were filtered with corner frequency set at $10 \mathrm{~Hz}$, digitized (Digital Storage Oscilloscope, Nicolet 4094-B, Nicolet Texas Instruments Division, Madison, WI) and transferred to a computer for kinetic analysis. After normalization, records were fitted to the following equation:

$$
\operatorname{ATP}(t)=A\left(1-\exp \left(-t / t_{\mathrm{f}}\right)\right)^{2}+B\left(1-\exp \left(-t / t_{\mathrm{s}}\right)\right)^{2}
$$

where $A$ and $B$ represent the steady-state ATP level for each component and $t_{\mathrm{f}}$ and $t_{\mathrm{s}}$ the time constants for each of the secretion components (f, fast; s, slow). Relative amplitude coefficients, $A$ and $B$, were obtained from the fitting procedure and were used to calculate the absolute amount of ATP secreted by both fast and slow components of secretion.

\subsection{Materials}

Imipramine and desipramine were obtained from Sigma Chemical Co., St. Louis, MO; penicillin and streptomycin from Bio-Whittaker Bioproducts, Walkersville, MD, and bovine serum albumin from Calbiochem, La Jolla, CA. All other reagents were obtained from different commercial sources and were of the maximal available purity.

\section{Results}

\subsection{Nicotine-induced inward currents}

Nicotine $(10 \mu \mathrm{M})$ perfusion for $4 \mathrm{~s}$ evoked an inward current that amounted to $-155.1 \pm 10.7 \mathrm{pA}(n=42)$, producing a total net charge flux of $314.2 \pm 26.1 \mathrm{pC}(n=42)$. When the exposure to nicotine was repeated 15 min later, ratio $S_{2} / S_{1}$ for peak current was $0.95 \pm 0.03(n=7)$ and for charge influx was $0.9 \pm 0.08(n=7)$. The presence of tricyclic antidepressants during $\mathrm{S}_{2}$ produced a marked decrease in both peak current
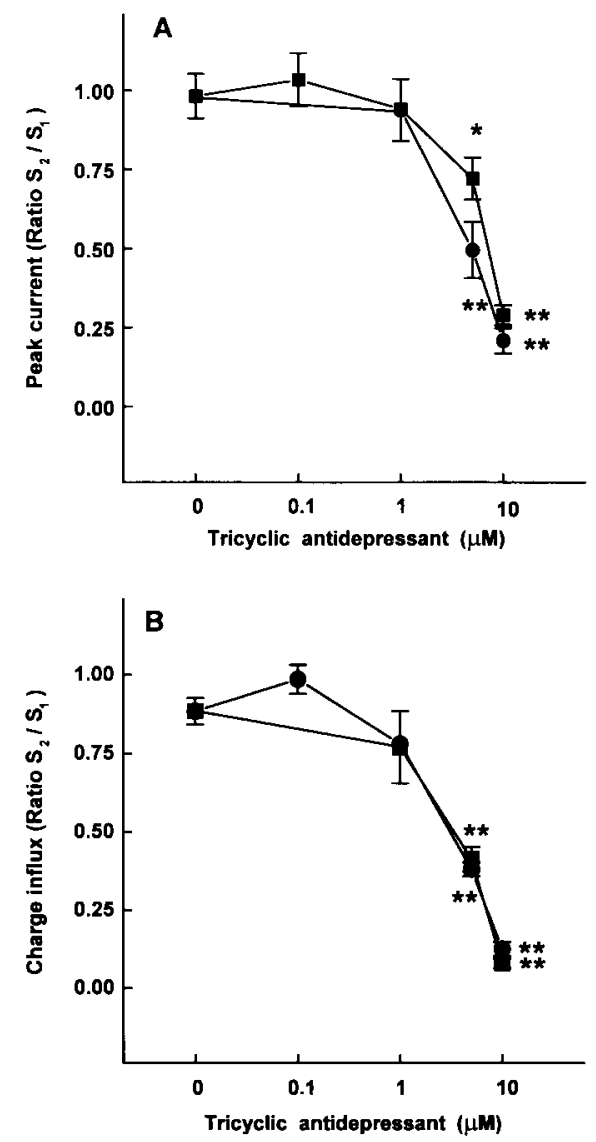

Fig. 2. Effect of tricyclic antidepressants on nicotine-induced peak currents (A) and total charge influx (B). The protocol was the same as in Fig. 1B. Peak current ratios were calculated from current records and charge influx ratios from current time integrals. Data represent mean \pm s.e. of 9 controls and 4 experiments for each imipramine $(\bullet)$ or desipramine $(\square)$ concentration. ${ }^{*} P<0.05$ and ${ }_{* *}^{*} P<0.01$ as compared to data in the absence of tricyclic antidepressants. 
and total charge flux that was reversible upon removal of the drug (Fig. 1). The inhibitory effect of imipramine and desipramine was dose-dependent. The blockade reached around $75 \%$ for peak current and $85 \%$ for total charge influx at 10 $\mu \mathrm{M}$ drug concentration (Fig. 2).

\subsection{ATP secretion and kinetics}

Nicotine $(10 \mu \mathrm{M})$ evoked the release of $22.2 \pm 1.9 \%$ of total ATP content in the cells $(n=14$; Table 1). Both imipramine and desipramine produced a dose-dependent inhibition of ATP secretion, being the blockade of ATP secretion complete at a concentration of $10 \mu \mathrm{M}$.

Kinetic studies have shown that ATP secretion from chromaffin cells has two components: one fast, that might represent secretion from docked vesicles and the other slow, accounting for refilling of docking sites by vesicles located inside the cell and its further secretion [21]. We have studied whether the blocking action of tricyclic antidepressants on nicotineinduced ATP secretion takes place on the fast or the slow component of secretion. As it can be observed in Fig. 3, both components of ATP secretion are affected in a dosedependent manner by imipramine and desipramine, being more important the inhibitory action on the slow component of secretion (Fig. 3B). However, time constant for the fast component of ATP secretion was not affected by the presence of tricyclic antidepressants, although the time constant for the slow component of secretion was markedly decreased by both imipramine and desipramine (data not shown).

\subsection{Effect of imipramine and desipramine on voltage-dependent $\mathrm{Ca}^{2+}$ currents}

Depolarization of chromaffin cells from a holding potential of $-55 \mathrm{mV}$ to $5 \mathrm{mV}$ for $10 \mathrm{~s}$ induced an inward current of $-193.9 \pm 13.6 \mathrm{pA}$ and the influx of $1.36 \pm 0.11$ fmoles of $\mathrm{Ca}^{2+}$ $(n=15)$. This current inactivated with a $\tau$ of $1.20 \pm 0.09 \mathrm{~s}$ (Fig. 4A). A second, identical, depolarization $\left(S_{2}\right)$ repeated $10 \mathrm{~min}$ later did not modify significantly $\mathrm{Ca}^{2+}$ entry (data not shown), being ratio $S_{2} / S_{1}$ for peak current $0.95 \pm 0.03$. When imipramine $(10 \mu \mathrm{M})$ was present $5 \mathrm{~min}$ before and during $S_{2}$ a marked decrease in peak current (ratio $S_{2} / S_{1}$ of $0.7 \pm 0.07$, $n=4$; Fig. 4B) could be observed. A similar effect was observed for desipramine $(10 \mu \mathrm{M})$ (Fig. 4B), being the ratio $\mathrm{S}_{2} /$ $\mathrm{S}_{1}$ for peak current $0.79 \pm 0.05(n=4)$.

\subsection{Effect of tricyclic antidepressant on depolarization-induced ATP secretion}

Exposure of chromaffin cells to high $\mathrm{K}^{+}(75 \mathrm{mM})$ evoked the secretion of about $17.3 \pm 1.1 \%$ of total ATP content in the cells. Imipramine produced a partial blockade (about $40 \%$ ) of
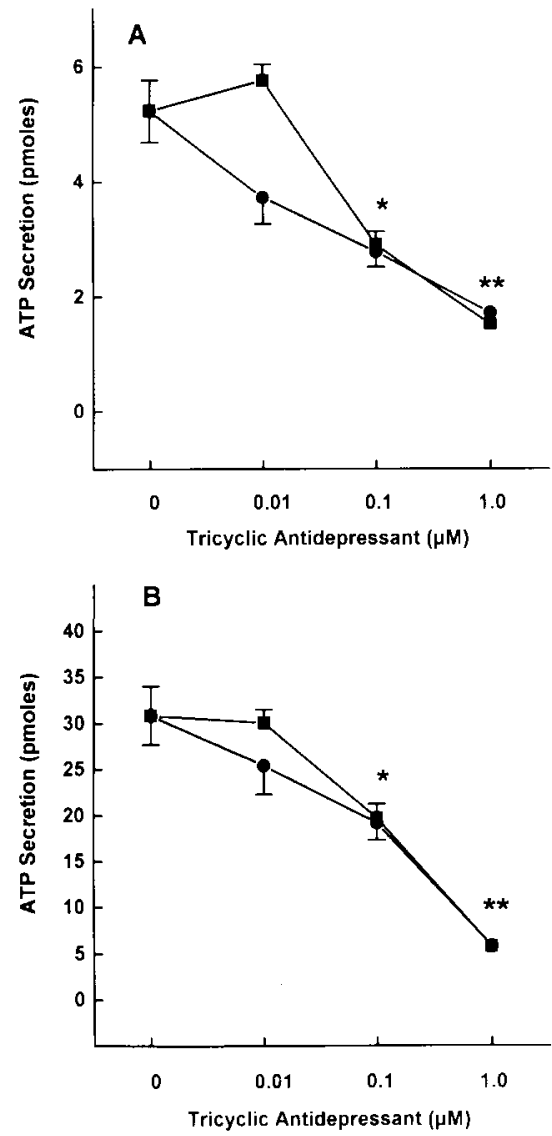

Fig. 3. Effect of imipramine (๑) and desipramine ( $\boldsymbol{\square})$ on nicotine-induced fast (A) and slow (B) components of ATP secretion. Data were calculated as stated in Section 2 and represent mean \pm s.e. of 20 experiments in the absence of antidepressant drugs and from 7 to 11 in the presence of either imipramine or desipramine. ${ }^{*} P<0.05$ and $* * P<0.01$ as compared to data in the absence of tricyclic antidepressants.

high $\mathrm{K}^{+}$-induced ATP secretion at a concentration of $10 \mu \mathrm{M}$ (Table 1). A similar action could be observed in the presence of desipramine (Table 1).

\section{Discussion}

The results presented here show that the tricyclic antidepressant drugs, imipramine and desipramine, potently block nicotine-induced ATP secretion from bovine chromaffin cells and that this effect might be explained by the potent and reversible blockade that these drugs produce on nicotine-induced currents in chromaffin cells. The blocking effect of ei-

Table 1

Effect of tricyclic antidepressants on nicotine $(10 \mu \mathrm{M})$ and high $\mathrm{K}^{+}-(75 \mathrm{mM})$-induced ATP secretion

\begin{tabular}{lcc}
\hline Tricyclic antidepressant & Nicotine $(10 \mu \mathrm{M})$ & $\mathrm{K}^{+}(75 \mathrm{mM})$ \\
\hline None & $22.22 \pm 1.90(n=22)$ & $17.30 \pm 1.06(n=20)$ \\
Imipramine $10 \mathrm{nM}$ & $13.79 \pm 0.52(n=9)^{*}$ & $14.85 \pm 0.35(n=7)$ \\
Imipramine $100 \mathrm{nM}$ & $11.96 \pm 0.66(n=8)^{*}$ & $14.82 \pm 1.21(n=11)$ \\
Imipramine $1 \mu \mathrm{M}$ & $3.82 \pm 0.65(n=8)^{*}$ & $10.50 \pm 1.06(n=9)^{*}$ \\
Desipramine $10 \mathrm{nM}$ & $20.08 \pm 1.12(n=5)$ & $14.50 \pm 0.49(n=7)^{*}$ \\
Desipramine $100 \mathrm{nM}$ & $14.64 \pm 1.96(n=6)^{*}$ & $12.54 \pm 1.46(n=8)^{*}$ \\
Desipramine $1 \mu \mathrm{M}$ & $9.35 \pm 1.83(n=9)^{*}$ & $9.47 \pm 1.25(n=9)^{*}$ \\
\hline
\end{tabular}

Secretion is expressed as fractional ATP secretion. Data represent mean \pm standard error of the number of experiments indicated in parenthesis. ${ }^{*} P<0.05$ as compared with control in absence of tricyclic antidepressants. 

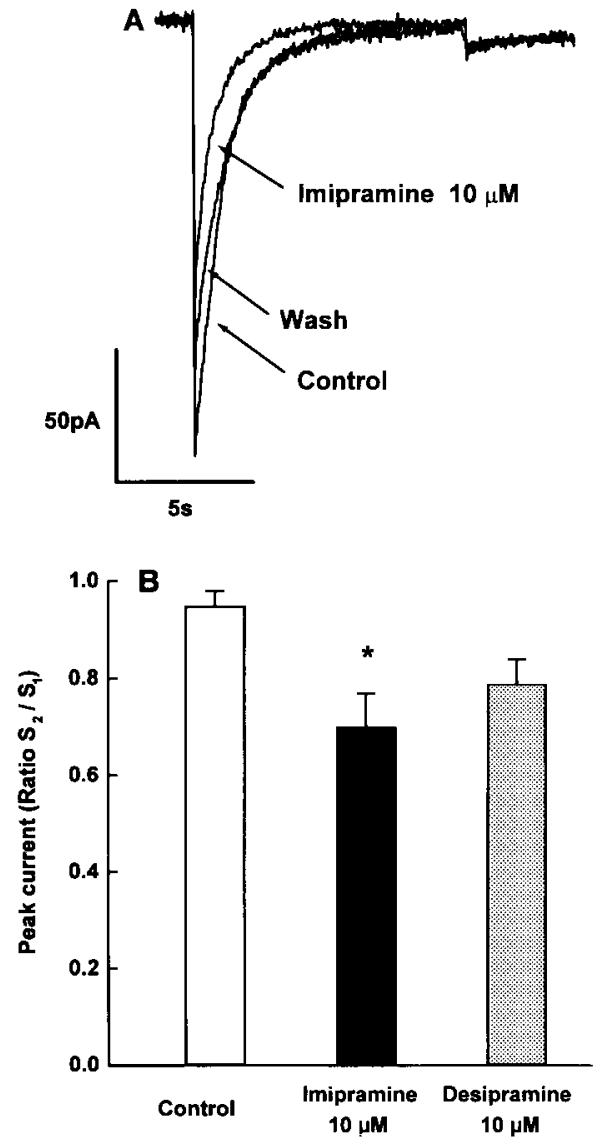

Fig. 4. Depolarization-induced $\mathrm{Ca}^{2+}$ currents in chromaffin cells. A: Inward $\mathrm{Ca}^{2+}$ currents induced in chromaffin cells by 3 consecutive depolarizing pulses $\left(S_{1}, S_{2}, S_{3}\right)$ from a holding potential of $-55 \mathrm{mV}$ to $5 \mathrm{mV}$ for $10 \mathrm{~s}$ applied $10 \mathrm{~min}$ apart. Five min before and during the second pulse imipramine $(10 \mu \mathrm{M})$ or desipramine $(10 \mu \mathrm{M})$ were present in the bath. B: Effect of imipramine $(10 \mu \mathrm{M})$ or desipramine $(10 \mu \mathrm{M})$ on peak $\mathrm{Ca}^{2+}$ currents. The protocol used was the same as in A. Data represent mean \pm s.e. of 4 experiments.

ther imipramine or desipramine on high $\mathrm{K}^{+}$-induced depolarization is less pronounced. However, certain degree of blockade of voltage-dependent $\mathrm{Ca}^{2+}$ currents can be observed, suggesting that a secondary target for the blocking actions of these drugs on nicotine-induced ATP secretion might be voltage-dependent $\mathrm{Ca}^{2+}$ channels.

The main finding of this work is that tricyclic antidepressants block much more efficiently nicotine-induced than high $\mathbf{K}^{+}$-induced ATP secretion. This effect might be explained by the blockade, by tricyclic antidepressants, of nicotine-activated receptor currents measured using the nystatin-perforated patch-clamp technique. This data might explain previous results that showed that imipramine was much more potent to block nicotine-induced than high $\mathrm{K}^{+}$-induced $\left[{ }^{3} \mathrm{H}\right]$ norepinephrine $\left({ }^{3} \mathrm{H}-\mathrm{NA}\right)$ secretion from chromaffin cells [16]. On the other side, it has been described that, in chromaffin cells, nicotine-induced currents through activation of cholinergic nicotinic receptors are blocked by a variety of drugs and toxins [12-15]. Taken together, these data indicate that the neuronal cholinergic nicotinic receptor might be a target through which different drugs and toxins might modulate the secretory activity of bovine chromaffin cells.

Tricyclic antidepressants also partially blocked depolariza- tion-induced ATP secretion, suggesting that, besides the actions on neuronal nicotinic receptors, an effect on voltagedependent $\mathrm{Ca}^{2+}$ channels might take place. High concentrations $(10 \mu \mathrm{M})$ of either imipramine or desipramine produced a similar degree of blockade (about $40 \%$ ) of peak current in response to long depolarizing pulses and of high $\mathrm{K}^{+}$-induced ATP secretion. This would suggest that a secondary target for the blocking effects of tricyclic antidepressant on ATP secretion might be voltage-dependent $\mathrm{Ca}^{2+}$ channels. These data would agree with a previous report showing that both imipramine and desipramine partially blocked ${ }^{45} \mathrm{Ca}^{2+}$ uptake in response to high $\mathrm{K}^{+}$in rat brain cortex synaptosomes [22].

In summary, the data presented here suggest that tricyclic antidepressants block nicotine-induced CA and ATP secretion by acting on two targets: one is the nicotinic receptor itself and the second one is voltage-dependent $\mathrm{Ca}^{2+}$ channels.

Acknowledgements: The authors thank Mrs. Esperanza Gascó for superb technical assistance. This work has been supported in part by grants from Fondo de Investigaciones Sanitarias (95/1655) to C.G.G.; from DGICYT (PM92-0112), Comisión Interministerial de Ciencia y Tecnología, Plan Nacional de Salud (SAF96-0169) and Fundación Navarro-Trípodi to V.C.

\section{References}

[1] Iversen, L.L. (1975) in: Handbook of Psychopharmacology (Iversen, L.L., Iversen, S.D. and Snyder, S.H., Eds.), Vol. 3, pp. 381-442, Plenum Press, New York.

[2] Snyder, S.H. and Yamamura, H.I. (1977) Arch. Gen. Psychiat. $34,236-241$.

[3] Rana, B., McMorn, S.O., Reeve, H.L., Wyatt, C.N., Vaughan, P.F.T. and Peers, C. (1993) Eur. J. Pharmacol. 250, 247-251.

[4] U'Pritchard, D.C., Greenburg, G.A., Sehan, P.P. and Snyder, S.H. (1978) Science 199, 197-199.

[5] Burgoyne, R.D. (1991) Biochim. Biophys. Acta 1071, 174-202.

[6] Matthews, E.K. (1967) J. Physiol. Lond. 189, 139-148.

[7] Douglas, W.W., Kanno, T. and Sampson, S.R. (1967) J. Physiol. Lond. 191, 107-121.

[8] Fenwick, E.M., Marty, A. and Neher, E. (1982) J. Physiol. Lond. $331,599-635$.

[9] Ceña, V., Stutzin, A. and Rojas, E. (1989) J. Membr. Biol. 112, 255-265.

[10] Cheek, T.R., Jackson, T.R., O’Sullivan, A.J., Moreton, R.B., Berridge, M.J. and Burgoyne, R.D. (1989) J. Cell Biol. 109, 1219-1227.

[11] Douglas, W.W. and Poisner, A.M. (1966) J. Physiol. Lond. 183, 249-256.

[12] López, M.G., Fonteríz, R.I., Gandia, L., De La Fuente, M., Villarroya, M., García-Sancho, J. and García, A.G. (1993) Eur. J. Pharmacol. 247, 199-207.

[13] Fernández, J.M., Granja, R., Izaguirre, V., González-García, C. and Ceña, V. (1995) Neurosci. Lett. 191, 59-62.

[14] Granja, R., Fernández-Fernández, J.M., Izaguirre, V., GonzálezGarcía, C. and Ceña, V. (1995) FEBS Lett. 362, 15-18.

[15] Nooney, J.M. and Feltz, A. (1995) Br. J. Pharmacol. 114, 648655.

[16] Ceña, V., Nicolas, G.P., Sanchez-García, P., Kirpekar, S.M. and García, A.G. (1983) Neuroscience 4, 1455-1462.

[17] Holz, R.W. and Senter, R.A. (1981) Science 214, 466-468.

[18] Armstrong, C.M. and Bezanilla, F. (1974) J. Gen. Physiol. 63, $533-552$.

[19] Ceña, V. and Rojas, E. (1990) Biochim. Biophys. Acta 1023, 213 222.

[20] Rojas, E., Pollard, H.B. and Heldman, E. (1985) FEBS Lett. 185, (2) 323-327.

[21] Von Rüden, L. and Neher, E. (1993) Science 262, 1061-1065.

[22] Lavoie, P.A., Beauchamp, G. and Elie, R. (1990) Can. J. Physiol. Pharmacol. 68, 1414-1418. 